\title{
The Muntingia calabura Leaves Extract Effect on Respiration and Heart Performance of Zebrafish (Danio rerio): The Search for Covid-19 Control Agent
}

\author{
Siti Zar'ah ${ }^{1,2}$, and Bambang Retnoaji ${ }^{1}$ \\ \{bambang.retnoaji@ugm.ac.id\} \\ ${ }^{1}$ Departement of Biology, Universitas Gadjah Mada, Jl. Teknika Selatan Sekip Utara, 55281, Indonesia, \\ ${ }^{2}$ Master Program in Biology, Graduate School, Departement of Biology, Universitas Gadjah Mada, Jl. \\ Teknika Selatan Sekip Utara, 55281, Indonesia
}

\begin{abstract}
Currently, the world community faces the Covid-19 pandemic phenomenon since December 2019 and has caused many victims. Various methods have been used to prevent and treat patients affected by this viral infection, especially in medical care. In addition to medical efforts, exploring natural material potential as a controlling agent for Covid-19 has been widely carried out. The purpose of this study was to examine the potential of Muntingia calabura as a controlling agent for Covid-19, by studying the secondary metabolite effects of Muntingia calabura leaves on zebrafish (Danio rerio). Research focuses on the administration of Muntingia calabura leaves extract and its impact on the organ respiration, heart rate and swim mobility on zebrafish (Danio rerio) by microscopic and macroscopic observations. The Muntingia calabura leaves were extracted following the soxhlet method, which then used as supplement of zebrafish feed. The zebrafish were divided into 5 groups, of control and those treated with leave extract of $0.5 \mathrm{mg} / \mathrm{L}, 0.25 \mathrm{mg} / \mathrm{L}, 0.1 \mathrm{mg} / \mathrm{L}$, and BSA alone, respectively. The results showed that Muntingia calabura leaves extract caused significant effects on zebrafish that decreased operculum opening, heart rate, and swim mobility. Data were analyzed with One-Way ANOVA, with the LSD Post Hoc Test and Duncan (DMRT), to determine the differences between each treatment group.
\end{abstract}

Keywords: Mutingia calabura, leaves, zebrafish, heart rate, respiration

\section{Introduction}

New cases of pneumonia were first reported in Wuhan, Hubei Province, in 2019. Five patients were diagnosed with Acute Respiratory Distress Syndrome (ARDS) from 18 to December 29 2019. The samples studied showed the etiology of the new coronavirus [1]. COVID-19 was first reported in Indonesia on March 2, 2020, in two cases [2]. Due to COVID-19 in Indonesia, the mortality rate is $8.9 \%$; this figure is the highest in Southeast Asia [2]. Coronavirus is an RNA virus with a particle size of $120-160 \mathrm{~nm}$. Coronavirus, which is the etiology of Covid-19, belongs to the genus betacoronavirus. The results of computer modeling show that SARS-CoV-2 has a 3-dimensional structure in the binding receptor spike domain protein similar to SARS-CoV. 
In SARS-CoV, this protein has a strong affinity for angiotensin-converting-enzyme 2 (ACE2) [3]. In SARS-CoV-2, in vitro data supported the possibility that the virus could enter cells using the ACE2 receptor [4]. ACE2 receptor expression is found in several extrapulmonary tissues such as the heart, kidney, endothelium, and gastrointestinal tract [5]. ACE2 is highly expressed on the digestive tract epithelium cells' lumen surface, which functions as a co-receptor in obtaining food and specifically for the absorption of amino acids from food. The ACE2 network is scattered in other organs and may explain the multi-organ damage observed in Covid-19 patients [6].

Muntingia calabura is a widely grown plant in Indonesia and people do not know much about Muntingia calabura's benefits, and it causes many Muntingia calabura not to be used, especially in the health sector [7]. The Muntingia calabura is one of the plants used as traditional medicine or herbal medicine by the community. This plant's chemical constituents have been scientifically proven to have compounds of the flavonoid group and have good biological activity. Therefore, Muntingia calabura plants have great potential in the field of pharmacology as a medicinal plant.

Further research also needs to be conducted to understand the bioactivity of compounds on Muntingia calabura leaf that have not been widely disclosed [8]. Zakaria (2007) reported that Muntingia calabura leaves have antipyretic and anti-inflammatory activity. It showed that anti-inflammatory effect of the Muntingia calabura extract, which could be due to biologically active chemical constituents in the extract. These findings serve as scientific support for Muntingia calabura plants' therapeutic use in traditional medicine [9].

The zebrafish (Danio rerio) were used as model organism in research for more than 100 years [10]. Zebrafish is used as a research tool on infectious diseases and host-pathogen interactions [11]. Several models of bacterial, viral, and fungal infections have been investigated using zebrafish [12]. Moreover, gills in fish are multifunctional organs that aid in critical physiological processes [13]. Therefore, study to reveal the potential of Muntingia calabura leaf for covid-19 control agent was urgently needed.

Bovine serum albumin (BSA) is a biologically stable globular protein used in various biochemical applications [14]. BSA is a plasma protein of cattle having $76 \%$ similarity with HAS (Human Serum Albumin) and composed of a single polypeptide chain consisting of more than 500 amino acid residues [15]. BSA effects on the sarcoplasmic reticulum channel important on lipid bilayer, which affects muscle contraction [16].

\section{Method}

\subsection{Research location}

The research was conducted at the Laboratory of Animal Structure and Development, Faculty of Biology, Universitas Gadjah Mada in October-November 2020.

\subsection{Muntingia calabura extraction}

The Muntingia calabura leaf extraction were conducted following standard soxhletation method. The fresh Muntingia calabura leaves number 3-5 from the tip were collected and 
washed with clean running water, drained, and dried at $36^{\circ} \mathrm{C}$ in an open air. The dried leaves were then mashed with blender, to get leaf powder, which then be wrapped with filter paper and put in a round bottom flask on the sox. The process was carried out at $70^{\circ} \mathrm{C}$ until the drops on the cycle are colorless. The extract obtained was concentrated with rotary evaporator at $55^{\circ} \mathrm{C}$ until it got a thick extract from ethanol. The thick extract of Muntingia calabura leaves was put on oven at $50^{\circ} \mathrm{C}$ to remove moisture.

\subsection{Leaf extract pellets}

Takari brand fish feed of 40 grams were gindedr and divided into 4 different containers. 5 $\mathrm{ml}$ of Muntingia calabura leaf extract solution is mixed in 10 grams of feed with concentrations of $0.5 \mathrm{mg} / \mathrm{L}, 0.25 \mathrm{mg} / \mathrm{L}$, and $0.1 \mathrm{mg} / \mathrm{L}$, repelleted with pelleter and dried.

\subsection{Zebrafish maintenance}

Wild type zebrafish (Danio rerio) were obtained from Leiden University and cultivated at the Faculty of Biology, UGM. The fish were maintained in a cycled aquarium at room temperature between $27-28.5^{\circ} \mathrm{C}$ and feed three times a day. Zebrafish broodstock are spawned to obtain eggs that will be reared until the age of 1 month for treatment. Adult zebrafish are placed in an aquarium of $8 \mathrm{~cm} \times 8 \mathrm{~cm}$ and a height of $10 \mathrm{~cm}$.

\subsection{Preparations of BSA solution}

Bovin Serum Albumin (BSA) was used as irritant or stressor to induce the stress on the fish, which then be treated with the extract. $0.1 \mathrm{~g}$ of BSA was dissolved in $1 \mathrm{~L}$ of water. BSA solution was put into the treatment aquarium as much as $250 \mathrm{~mL}$ for 4 aquariums, 1 aquarium filled with normal water. BSA solution was used to induce immune effect of the zebrafish in the aquarium and as a negative control.

\subsection{Treatment of extract-feeding}

Zebrafish WT AB/TL strain were used as experimental animals, which were grouped into five group, namely: 1) Control (zebrafish in water media with regular fish feed), 2) negative control (zebrafish in BSA solution with ordinary fish feed), 3) zebrafish in BSA solution + Muntingia calabura leaf extract $0.5 \mathrm{mg} / \mathrm{L}, 4)$ zebrafish in BSA solution + Muntingia calabura y leaf extract $0.25 \mathrm{mg} / \mathrm{L}$, and 5) zebrafish in a solution of BSA + Muntingia calabura leaf extract $0.1 \mathrm{mg} / \mathrm{L}$. The zebrafish were feed with Muntingia calabura leaf extract or regular pellet 3 times a day for 14 days.

\subsection{Data collections}

All group treatments were observed with a Leica DM750 microscope to determine zebrafish frequency of operculum opening and heart rate. Operculum opening frequency was observed by counting zebrafish's operculum opening in 1 minute. Heart rate was observed by counting heartbeats in 1 minute period.

The zebrafish range is determined by dividing the area in the aquarium. An aquarium with a base of $8 \mathrm{~cm} \times 8 \mathrm{~cm}$ and a height of $10 \mathrm{~cm}$ is divided into 4 places shown in figure 3.4. The zebrafish movement is calculated based on the number of zebrafish across the divided side in one minute. 


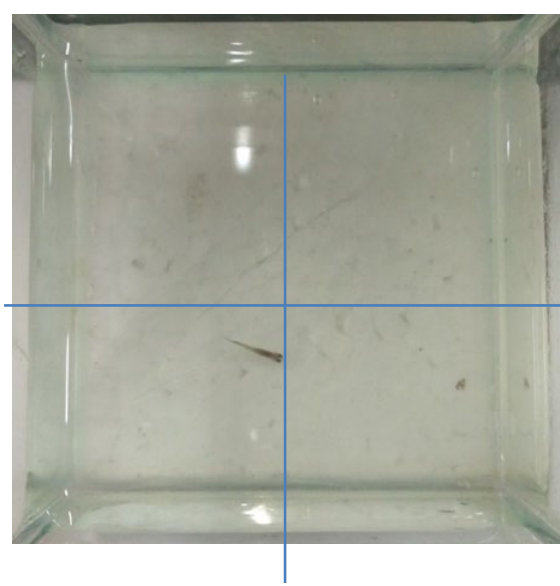

Figure 2.1. The distribution of zebrafish swimming ranges in the aquarium.

\subsection{Statistical analysis}

Statistical analysis was performed using IBM SPSS Statistics 25. One Way ANOVA test was used to determine differences between treatment groups of various Muntingia calabura extract concentrations. Data were presented as mean, standard deviation and were considered significant if $\mathrm{P}<0.05$.

\section{Results and Discussion}

\subsection{Effect of Muntingia calabura extract on zebrafish operculum opening frequence}

The result showed the variation of operculum opening on the fish of control and treated fish as presented on Figure 3.1.

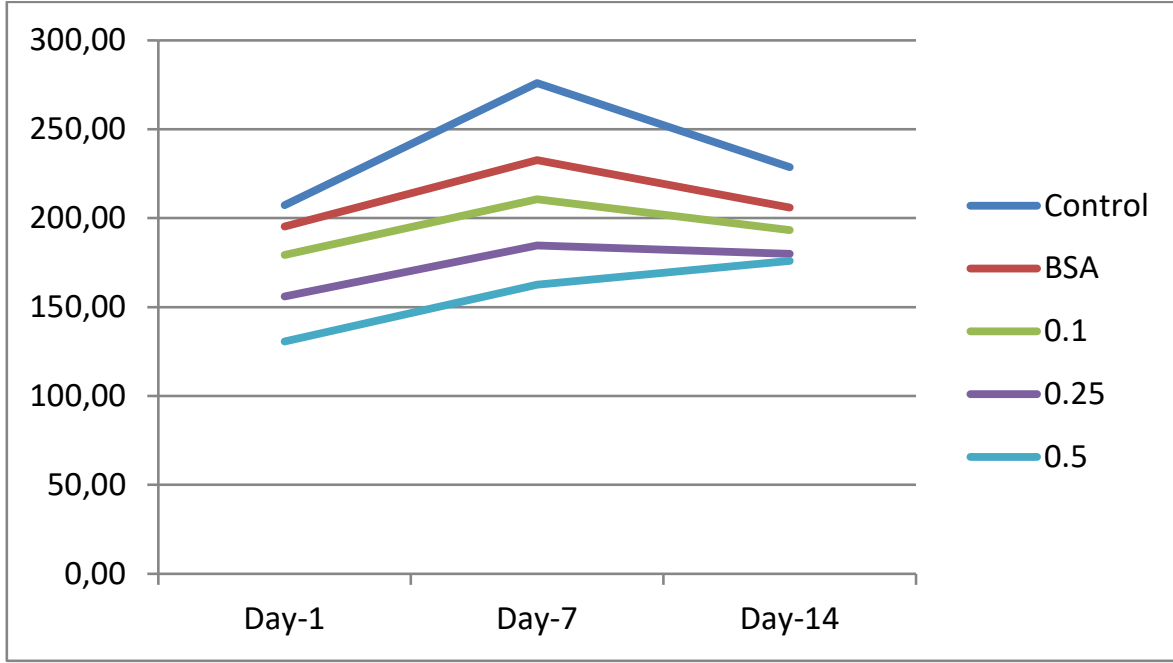

Figure 3.1. Frequency of zebrafish operculum opening on the first, seventh and fourteenth day. 
Data showed that the most frequent of operculum opening frequency was performed by the control group at the first day of treatment. On the other hand, the lest operculum opening frequent was showed by $0.5 \mathrm{mg} / \mathrm{L}$ leaf extract treatment group on the fourteenth day. The data also showed that on $0.1 \mathrm{mg} / \mathrm{L}$ group and $0.5 \mathrm{mg} / \mathrm{L}$ group were decreased operculum opening on seventh day and fourteenth day. Control group, BSA and $0.25 \mathrm{mg} / \mathrm{L}$ group were decreased from first until fourteenth day.

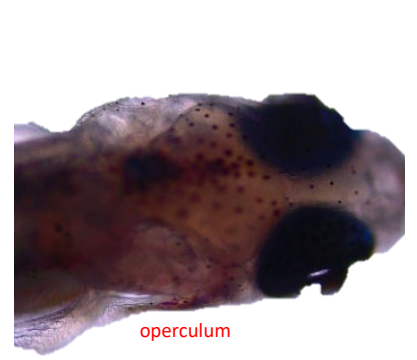

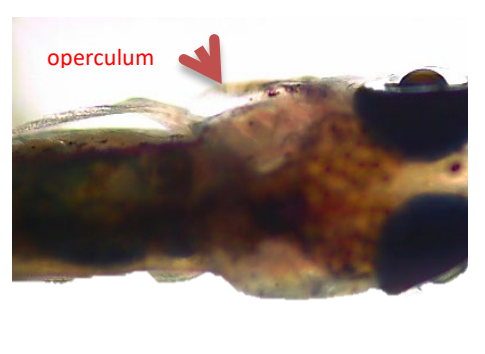

b

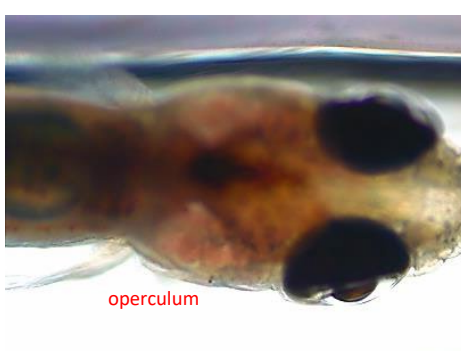

c

Figure 3.2. Operculum opening on the zebrafish, a) zebrafish on the first day, b) zebrafish on the seventh day, c) zebrafish on the fourteenth day.

\subsection{Effect of Muntingia calabura extract as feed on zebrafish heart rate}

Result showed the decrease in heart rate from the first day to the fourteenth day occurred in the extract treatment group $0.1 \mathrm{mg} / \mathrm{L}, 0.25 \mathrm{mg} / \mathrm{L}$ and $0.5 \mathrm{mg} / \mathrm{L}$, while the BSA group was the group with the highest increase in heart rate (Figure 3.3.). The heart rate of adult zebrafish ranges from $120-130$ beats per minute at $28^{\circ} \mathrm{C}$ [17].

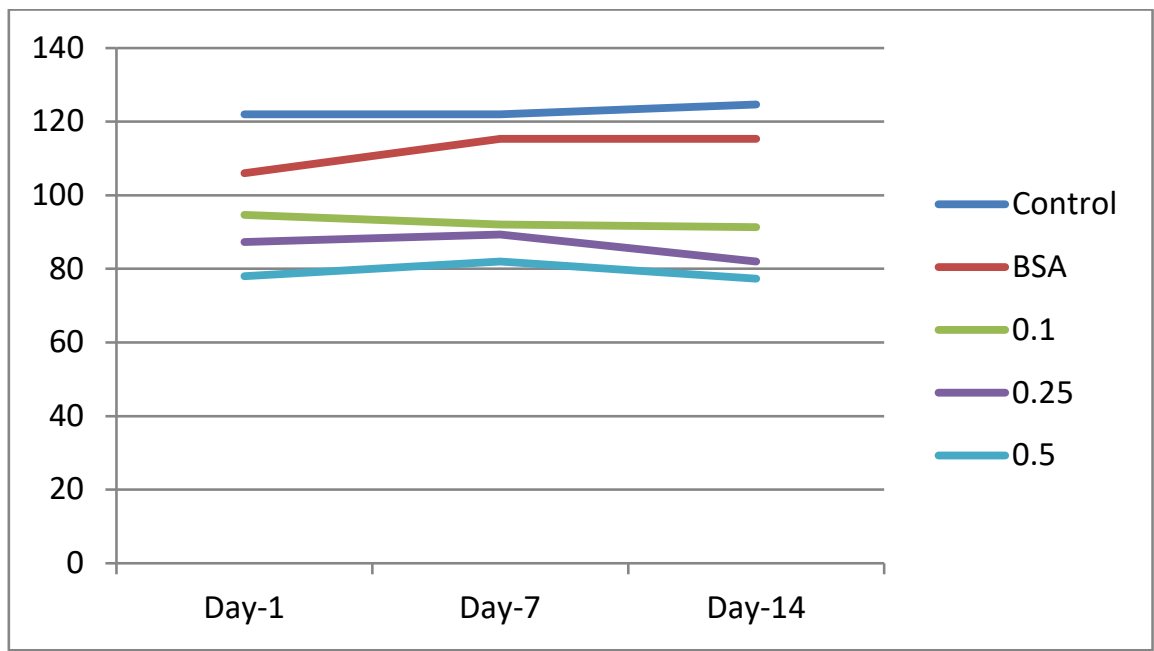

Figure 3.3. Zebrafish heart rate on the first, seventh and fourteenth day. 
The renin-angiotensin-aldosterone system is a major factor in maintaining arterial blood pressure. One of the target components is angiotensin-converting enzyme (ACE) which functions as a regulator of arterial blood pressure and electrolyte balance through the reninangiotensin-aldosterone system. The highest concentration of ACE is in the capillaries of the respiratory organs. ACE is also found in the proximal tubule of the kidney, gastrointestinal tract, heart and brain [18]. Muntingia calabura leaves contain a group of compounds including flavonoids, phenolics, triterpenoids. Qualitatively, it is known that the most common compounds in Muntingia calabura leaves are flavonoids [19]. Several terpenoid and polyphenolic compounds including flavonoids, tannins, xanthones, procyanidins, caffeolyquinic acid derivatives are effective natural ACE inhibitors. Previous studies have shown that plant extracts rich in phytocemicals are effective as ACE inhibitors [18].

\subsection{Effect of Muntingia calabura extract as feed on zebrafish swim mobility}

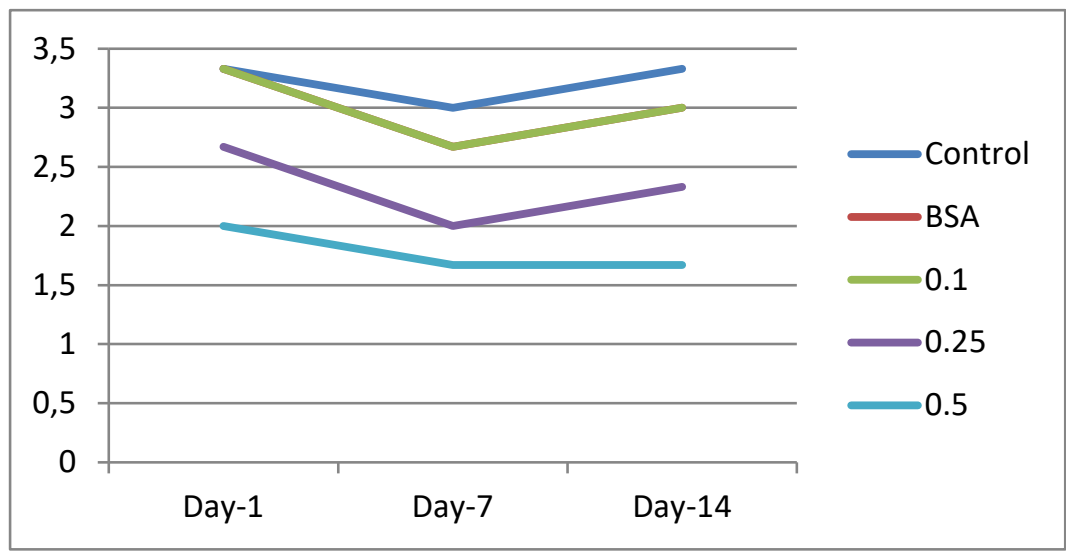

Figure 3.4. Swim mobility on the first, seventh and fourteenth day.
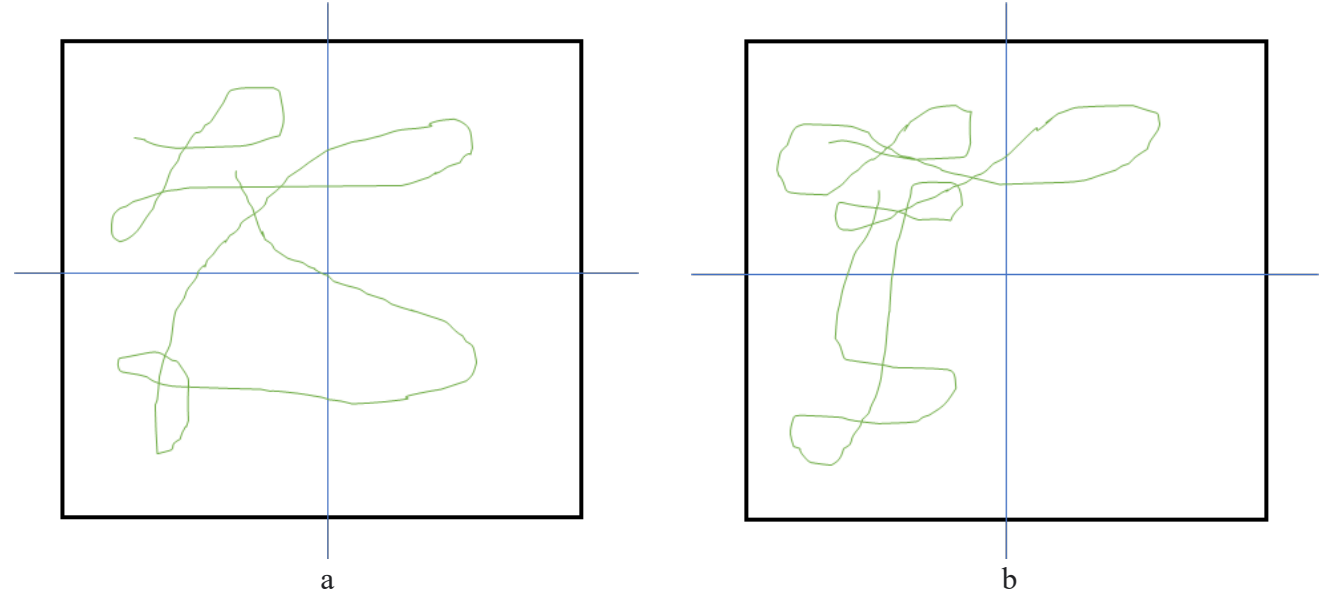

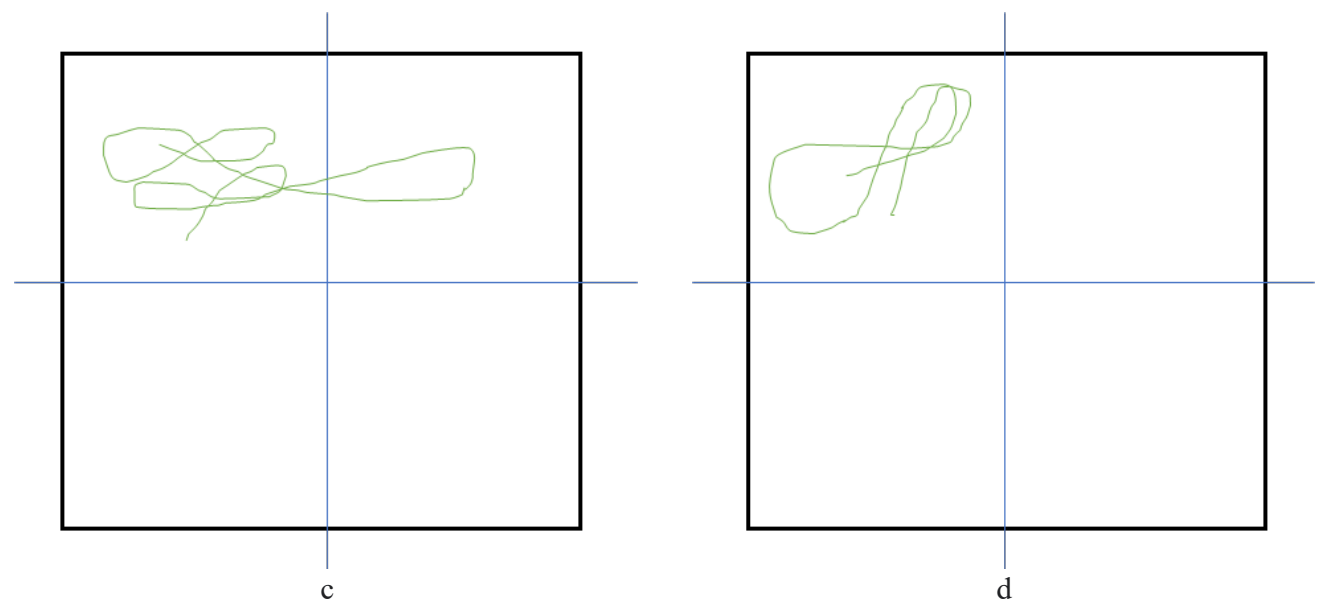

Figure 3.5. Swim pattern of zebrafish that were observed from above of aquarium. a) Swim pattern on control group, b) Swim pattern on BSA and $0.10 .1 \mathrm{mg} / \mathrm{L}$ group, c) Swim pattern on $0.25 \mathrm{mg} / \mathrm{L}$ group, d) Swim pattern on $0.5 \mathrm{mg} / \mathrm{L}$ group.

Figure 3.4 showed that the data on the effect of the Muntingia calabura extract on the zebrafish swim mobility. The graph depicts the value that tends to decrease with increasing treatment concentration. The decrease in the chart is thought to have been strongly influenced by the induction of BSA and Muntingia calabura extract in several concentrations. The BSA group and the $0.1 \mathrm{mg} / \mathrm{L}$ treatment group had the same trend, namely a decrease in the seventh day and an increase on the fourteenth day. Figure 3.5 showed that the swim pattern of zebrafish after treatment. Based on the swimming pattern of zebrafish, it showed that the cruising range was highest in the control group, namely zebrafish passing all sides of the aquarium in one minute. The zebrafish in the BSA group and the $0.1 \mathrm{mg} / \mathrm{L}$ treatment group had the same range of ranges across 3 sides in the aquarium. The zebrafish in the $0.5 \mathrm{mg} / \mathrm{L}$ treatment group had the lowest range of all treatment groups, which only stayed on one side of the aquarium.

BSA can induce several chemical secretions, one of which is interleukin-4 (IL-4) [20]. Interleukin-4 (IL-4) has a significant function in activating the heart rate. The increased heart rate value in BSA treatment influences the zebrafish operculum's opening frequency shown in Figure 3.3. Heart rate can be decreased due to BSA by giving Muntingia calabura leaf extract. The antioxidants in Muntingia calabura have a particular function in increasing immunity [21], so that the Muntingia calabura extract added to the BSA treatment has the effect of decreasing the value of the heart rate, operculum opening and swim mobility at average values.

In observing the behavior, the control group zebrafish was more responsive to feeding with Muntingia calabura leaf extract as the treatment in this study. These data indicated that the extract concentration of $0.5 \mathrm{mg} / \mathrm{L}$ caused a decrease in operculum opening, heart rate and swim mobility higher than the other treatment groups. Based on the LC50 test, the concentration of $0.5 \mathrm{mg} / \mathrm{L}$ of Muntingia calabura leaf extract is the limit for the concentration of surviving zebrafish, it means that the $0.5 \mathrm{mg} / \mathrm{L}$ or higher concentration of Muntingia calabura leaf extract has a toxic potential to zebrafish, because increasing the extract 
concentration can decreased the operculum opening, heart rate and swim mobility. The extract at a dose of $0.5 \mathrm{mg} / \mathrm{L}$ was not effective because the results obtained were not the same as the control group.

The data of the research findings are linear with the one-way ANOVA statistical test conducted. The statistical test results showed that Muntingia calabura leaf extract significantly decreased operculum opening, heart rate and swim mobility of zebrafish.

\section{Conclusion}

This study concludes that Muntingia calabura leaves have potential as a controlling agent for Covid-19, by studying the secondary metabolite effects of Muntingia calabura leaves on zebrafish (Danio rerio). Muntungia calabura leaf extract has potential to induce the physiologies respond of the zebrafish, evidenced by significant decreased operculum opening, heart rate, and swim mobility of zebrafish. The extract toxicity effect on fish in this study was indicated on the concentration of higher than $0.1 \mathrm{mg} / \mathrm{L}$ of the extract.

Acknowledgment. The authors acknowledge all people involved in this research, Universitas Gadjah Mada and financial support provided by KEMENRISTEKDIKTI through Penelitian Tesis Magister 2020. Letter Task No.6/AMD/E1/KP.PTNBH/2020 and 3009/UN1.DITLIT/DIT-LIT/PT/2020.

\section{References}

[1] Ren L-L, Wang Y-M, Wu Z-Q, Xiang Z-C, Guo L, Xu T, et al. Identification of a novel coronavirus causing severe pneumonia in human: a descriptive study. Chin Med J. 2020; published online February 11. DOI: 10.1097/CM9.0000000000000722.

[2] Adityo Susilo C. Martin Rumende, Ceva W Pitoyo, Widayat Djoko Santoso et al. 2020. Coronavirus Disease 2019: Tinjauan Literatur Terkini. Jurnal Penyakit Dalam Indonesia Vol 7, No 1.

[3] Zhang, Haibo, Josef M. Penninger, Yimin Li, Nanshan Zhong and Arthur S. Slutsky. 2020. Angiotensin-converting enzyme 2 (ACE2) as a SARS-CoV-2 receptor: molecular mechanisms and potential therapeutic target. Intensive Care Med (2020) 46:586-590.

[4] Zhou P, Yang X-L, Wang X-G, Hu B, Zhang L, Zhang W, et al. A pneumonia outbreak associated with a new coronavirus of probable bat origin. Nature. 2020;579(7798):270-3.

[5] Crackower MA, Sarao R, Oudit GY, Yagil C, Kozieradzki I, Scanga SE, Oliveira-dos-Santos AJ, da Costa J, Zhang L, Pei Y, Scholey J, Ferrario CM, Manoukian AS, Chappell MC, Backx PH, Yagil Y, Penninger JM (2002) Angiotensin-converting enzyme 2 is an essential regulator of heart function. Nature 417(6891):822-828.

[6] Wang D, Hu B, Hu C, Zhu F, Liu X, Zhang J, Wang B, Xiang H, Cheng Z, Xiong Y, Zhao Y, Li Y, Wang X, Peng Z. 2020. Clinical characteristics of 138 hospitalized patients with 2019 novel coronavirus-infected pneumonia in Wuhan, China. JAMA. https://doi.org/10.1001/jama.2020.1585. 
[7] Gomathi R, Anusuya N and Manian S. A Dietary Antioxidant Supplementation of Jamaican Cherries (Muntingia calabura Linn) Attenuates Inflammatory Related Disorders. 2013. Food Sci.Biotechnol.

[8] Devi Anggraini Putri dan Sri Fatmawati. 2019. Metabolit Sekunder dari Muntingia calabura dan Bioaktivitasnya. Laboratorium Kimia Bahan Alam dan Sintesis, Departemen Kimia, Institut Teknologi Sepuluh Nopember, Kampus ITS Sukolilo. ALCHEMY Jurnal Penelitian Kimia, Vol. 15(1) 2019, 57-78.

[9] Kathirvel Preethi, Paramasivam Premasudha, Kittusamy Keerthana. 2012. Anti-inflammatory Activity of Muntingia calabura Fruits. Pharmacognosy Journal Volume 4, Issue 30, July-August 2012, Pages 51-56.

[10] Sullivan, C., Kim, C.H., 2008. Zebrafish as a model for infectious disease and immune function. Fish. Shellfish Immunol. 25, 341e350.

[11] Novoa, B., Figueras, A., 2012. Zebrafish: model for the study of inflammation and the innate immune response to infectious diseases. Adv. Exp. Med. Biol. 946, 253e275.

[12] Davis, J.M., Clay, H., Lewis, J.L., Ghori, N., Herbomel, P., Ramakrishnan, L., 2002. Realtime visualization of mycobacterium-macrophage interactions leading to initiation of granuloma formation in zebrafish embryos. Immumity 17, 693e702.

[13] Evans, D.H., Piermarini, P.M., Choe, K.P., 2005. The multifunctional fish gill: dominant site of gas exchange, osmoregulation, acid-base regulation, and excretion of nitrogenous waste. Physiol. Rev. $85,97-177$.

[14] Regina $\mathrm{M}$ et al., 2016. The Process of Separating Bovine Serum Albumin Using Hydroxyapatite and Active Babassu Coal ( Orbignya martiana ) Sci. World J.

[15] Rombouts I Lagrain B Scherf K A Koehler P and Delcour J A, 2015 Formation and reshuffling of disulfide bonds in bovine serum albumin demonstrated using tandem mass spectrometry with collision-induced and electron- transfer dissociation Nat. Publ. Gr. June p. 1-11.

[16] Xiyuan Z Fink R H A and Mosqueira M, 2017 NO-sGC Pathway Modulates Ca 2 + Release and Muscle Contraction in Zebrafish Skeletal Muscle Front. Physiol. 8, August.

[17] Verkerk A. O. and Remme C. A. (2012). Zebrafish: a novel research tool for cardiac (patho)electrophysiology and ion channel disorders. Front. Physiol. 3, 255 10.3389/fphys.2012.00255.

[18] B.W. Nileeka Balasuriya HPVR. Plant flavonoids as angiotensin converting enzyme inhibitors in regulation of hypertension. Funct Foods Heal Dis. 2011;1(5):172-88. Balasse, Emilie, Johann Odot, Gregory Gatouillat, Claudie Madoulet. 2008. Enhanced immune response induced by BSA loaded in hydroxyethylstarch microparticles. International Journal of Pharmaceutics 353(1-2):1318.

[19] Nijveldt, R. J., E. van Nood, D.E.C. van Hoorn, P.G. Boelens, K. van Norren, P.A.M. van Leeuwen. Flavonoids: a review of probable mechanisms of action and potential applications. American Journal of Clinical and Nutrition. 2001. Hal 418-425.

[20] Balasse, Emilie, Johann Odot, Gregory Gatouillat, Claudie Madoulet. 2008. Enhanced immune response induced by BSA loaded in hydroxyethylstarch microparticles. International Journal of Pharmaceutics 353(1-2):131-8.

[21] Zakaria, Z.A., Sani, M.H.M., Cheema, M.S. et al. 2014. Antinociceptive activity of methanolic extract of Muntingia calabura leaves: further elucidation of the possible mechanisms. BMC Complement Altern Med 14, 63. https://doi.org/10.1186/1472-6882-14-63. 